\title{
ANALISA DAN PERANCANGAN APLIKASI SISTEM INVENTORY (STUDI KASUS: PT. CAKRA MEDIKA UTAMA)
}

\author{
Sitiani Zalukhu ${ }^{1}$, Inge Handriani ${ }^{2}$ \\ Program Studi Sistem Informasi, Fakultas Ilmu Komputer, Universitas Mercu Buana \\ Jl. Raya Meruya Selatan, Kembangan, Jakarta, 11650 \\ 41814120183@student.mercubuana.ac.id ${ }^{1}$, Inge.handriani@mercubuana.ac.id ${ }^{2}$
}

\begin{abstract}
PT. Cakra Medika Utama is the company main the medical equipment distributor.As for the problems frequently encountered by on a system that in its current operation this is the the data collection and reporting an inventory of goods in and out at the are still being undertaken in the ledger that need the time which long enough in the completion of each of the required information.The existence of goods by which expiration is not speed locations because there is no notice. The purpose of this research is to make information system design of inventory items that can be reduce disadvantages for goods that passes through minimum limit of the expiration date and improve the efficiency of recording an inventory of goods in and out by using the method of development rapid system application development (rad ). On designing inventory information system could help improve the efficiency of time in providing information on the availability of stocks of goods in a warehouse quickly and accurately
\end{abstract}

Abstrak - PT. Cakra Medika Utama merupakan perusahaan yang bergerak dibidang distributor alat kesehatan. Adapun masalah yang sering dihadapi pada sistem yang sedang berjalan saat ini yaitu proses pendataan dan pelaporan persediaan barang masuk dan keluar masih dilakukan secara pencatatan di buku besar yang memerlukan waktu yang cukup lama dalam menyelesaikan setiap informasi yang dibutuhkan. Adanya barang yang kadaluarsa tidak cepat di ketahui karena tidak adanya pemberitahuan. Tujuan penelitian ini adalah membuat perancangan sistem informasi inventory barang yang dapat meminimalisir kerugian atas barang yang melewati batas minimal tanggal kadaluarsa dan meningkatkan efisiensi pencatatan persediaan barang masuk dan keluar dengan menggunakan metode pengembangan sistem Rapid Application Development (RAD). Pada perancangan sistem informasi inventory ini dapat membantu meningkatkan efisiensi waktu dalam memberikan informasi ketersediaan stok barang yang ada di gudang secara cepat dan akurat

Keywords - Perancangan Sistem Informasi Inventory, PIECES, RAD.

\section{Pendahuluan}

Seiring berkembangnya kemajuan teknologi informasi dan komunikasi, persaingan bisnis dalam dunia industri semakin ketat. [1] Perkembangan teknologi informasi saat ini berdampak sangat besar dalam segala aspek kehidupan, termasuk dalam dunia bisnis. [2] Perkembangan teknologi pengetahuan, teknologi dan cara kerja manusia mengalami perkembangan yang sangat pesat sekali. Pekerjaan yang dulunya dilakukan dengan cara tradisional dan memerlukan banyak waktu dalam menyelesaikannya sekarang dapat dilakukan dengan bantuan peralatan yang canggih dan tidak memerlukan waktu yang terlalu lama dalam menyelesaikannya.

Aktifitas diperusahaan saat ini banyak menggunakan sistem yang terkomputerisasi untuk memudahkan karyawan dalam mengelolah data [3]. Banyak perusahaan yang bergerak dibidang perdagangan menggunakan aplikasi untuk meningkatkan produktifitas, baik dalam memperoleh data mengolah dan menggunakan data tersebut terutama untuk kepentingan intern perusahaan. [4] Pada masa sekarang ini banyak terdapat perusahaan yang mengalami masalah dalam menangani transaksi penjualan di perusahaannya. Oleh karena itu diperlukan suatu alat bantu yang bisa digunakan untuk mempercepat proses pengolahan data untuk menghasilkan informasi yang lebih akurat dan terpercaya sehingga bisa digunakan untuk pengambilan keputusan untuk pengembangan perusahaan di masa yang akan datang.

Perusahaan yang mampu mengendalikan dan mengelola inventory dengan baik akan dapat memenuhi kebutuhan pelanggan dan tentu saja dapat menjaga kelangsungan bisnisnya dalam dunia industri saat ini. Inventory barang didalam suatu usaha menjadi hal yang penting bagi suatu perusahaan, karena dari inventory tersebut bisa mengelola stok barang digudang yang nantinya 
akan dijual ke konsumen. [5] Dengan adanya sistem informasi, organisasi atau perusahaan dapat menjamin kualitas informasi yang disajikan dan dapat mengambil keputusan berdasarkan informasi tersebut. Sekarang informasi dapat diperoleh dengan lebih mudah dan cepat, berkat adanya teknologi informasi. Salah satu pemanfaatan teknologi informasi yang diharapkan adalah pada sistem inventory barang.

Masalah inventory terkadang masih menjadi salah satu kendala untuk mencapai tujuan perusahaan, karena sistem inventory yang tidak terkendali dan tidak adanya pengawasan yang benar serta metode yang dapat dijalankan dengan baik [6]. [7] Untuk memenuhi kebutuhan informasi, memerlukan pengolahan yang sistematis dengan cara membentuk suatu sistem informasi. Sistem persediaan barang sangat dibutuhkan oleh perusahaan, karena dengan sistem tersebut perusahaan dapat mendukung operasional usaha suatu perusahaan. Dalam penerapan sistem informasi perlu ditunjang dengan teknologi informasi yaitu pemanfaatan komputer beserta aplikasi-aplikasinya sebagai alat untuk mempercepat pendistribusian data dan informasi. [8] Dengan pekerjaan-pekerjaan yang biasanya selalu dilakukan secara manual oleh manusia akan semakin cepat dan efisien apabila dilakukan dengan sistem komputerisasi. Bahkan dengan kecanggihan teknologi komputer yang semakin berkembang dengan pesat dapat memudahkan perusahaanperusahaan tersebut untuk meningkatkan efisiensi kerja, karena pekerjaan yang dilakukan dengan komputer dapat menghemat baik dari segi waktu, ruang, tenaga, biaya dan lain-lain.

Seperti halnya pada perusahaan PT. Cakra Medika Utama yang bergerak dibidang distributor alat kesehatan belum maksimal memenuhi informasi kebutuhan inforrmasi secara optimal dimana proses pendataan dan pelaporan persediaan barang masih dilakukan secara pencatatan di buku besar yang memerlukan waktu yang cukup lama dalam menyelesaikan setiap informasi yang dibutuhkan. Untuk pendataan penerimaan barang masuk dilakukan dengan pencatatan di buku besar sesuai surat jalan sehingga dari pencatatan tersebut terkadang terjadi kesalahan dalam perhitungan barang, dan pembuatan laporan yang dihasilkan tidak tepat waktu dan kurang akurat, dan juga adanya barang yang kadaluarsa tidak cepat di ketahui karena tidak adanya pemberitahuan. Oleh karena diperlukan sebuah sistem informasi inventory yang terkomputerisasi guna mempermudah serta mempercepat proses pendataan stok barang masuk dan keluar sehingga sistem yang akan dibangun diharapkan dapat memberikan informasi yang cepat dan akurat yang dapat membantu pkerjaan pada departemen gudang.
Batasan masalah dalam penelitian ini mencakup informasi untuk proses inventory barang di PT. Cakra Medika Utama yang menghasilkan jumlah stok barang, laporan data inventory barang, input keluar masuk barang dan menampilkan notifikasi barang yang sudah mau mendekati tanggal kadaluarsa. Dengan menentukan tujuan penelitian ini untuk meningkatkan efisisensi pencatatan persediaan barang dan efisiensi waktu dalam memberikan informasi ketersediaan stok barang secara cepat dan akurat.

\section{Metode Penelitian}

Penelitian ini dilakukan dengan menggunakan metode kualitatif deskriptif. Pada penelitian ini mengambil objek mengenai sistem pencatatan dan pendataan inventory barang yang diterapkan pada PT. Cakra Medika Utama. Dengan pendekatan kualitatif dapat ditemukan data proses masuk dan keluar barang.

\section{Observasi}

Pengamatan langsung terhadap proses persediaan keluar masuk barang pada bagian gudang.

\section{Wawancara}

Kegiatan wawancara atau tanya jawab langsung dengan kepala gudang dan 3 orang staff pada Departemen Gudang.

\section{Studi Literatur}

Pengumpulan data dokumen secara langsung berupa kartu stok, laporan data keluar masuk barang dan surat jalan.

Tahapan yang dilakukan dalam penelitian ini adalah sebagai berikut:

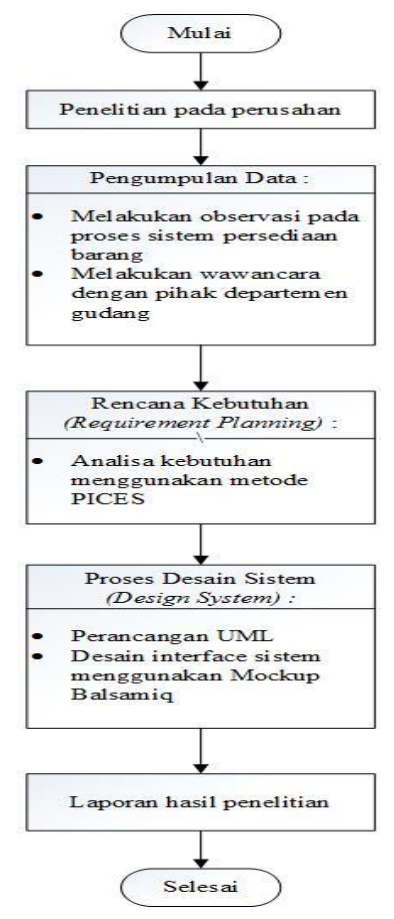

Gambar 1. Diagram Alur Penelitian 


\section{A. Metode Pengembangan Sistem}

Metode pengembangan sistem yang digunakan adalah Rapid Application Development (RAD). Rapid Application Development (RAD) adalah sebuah proses perkembangan perangkat lunak sekuensial linier yang menekankan siklus perkembangan dalam waktu yang singkat". RAD menggunakan metode iteratif (berulang) dalam mengembangkan sistem dimana working model (model bekerja) sistem dikonstruksikan di awal tahap pengembangan dengan tujuan menetapkan kebutuhan (requirement) pengguna dan selanjutnya disingkirkan. Dalam pengembangan sistem informasi normal, memerlukan waktu minimal 180 hari, namun dengan nggunakan metode RAD, sistem dapat diselesaikan dalam waktu 30-90 hari. Model RAD memiliki 3 tahapan sebagai berikut :

1. Rencana Kebutuhan (Requirement Planning)

User dan analyst melakukan pertemuan untuk mengidentifikasi tujuan dari sistem dan kebutuhan informasi untuk mencapai tujuan. Pada tahap ini merupakan hal terpenting yaitu adanya keterlibatan dari kedua belah pihak.

2. Proses Desain Sistem (Design System)

Pada tahap ini keaktifan user yang terlibat menentukan untuk mencapai tujuan karena pada proses ini melakukan proses desain dan melakukan perbaikan-perbaikan apabila masih terdapat ketidaksesuaian desain antara user dan analyst. Seorang user dapat langsung memberikan komentar apabila terdapat ketidaksesuaian pada desain, merancang sistem dengan mengacu pada dokumentasi kebutuhan user yang sudah dibuat pada tahap sebelumnya. Keluaran dari tahapan ini adalah spesifikasi software yang meliputi organisasi sistem secara umum, struktur data dan yang lain.

3. Implementasi (Implementation)

Tahapan ini adalahan tahapan programmer yang mengembangkan desain suatu program yang telah disetujui oleh user dan analyst. Sebelum diaplikasikan pada suatu organisasi terlebih dahulu dilakukan proses pengujian terhadap program tersebut apakah ada kesalahan atau tidak. Pada tahap ini user biasa memberikan tanggapan akan sistem yang sudah dibuat serta mendapat persetujuan mengenai sistem tersebut.

\section{B. Metode Analisis Sistem}

Pada tahap analisa sistem pada penelitian ini melakukan analisa menggunakan metode Analisa PIECES. PIECES adalah analisis yang melihat dari sudut (Performane, Information Data, Economic,
Control Security, Efficiency dan Service) untuk memberikan perbandingan kelebihan dan kekurangan dari sebuah analisa sistem untuk diberikan kesimpulan untuk sebuah perbaikan. ujuan analisa PIECES untuk memecahkan sebuah masalah dengan cara mengumpulkan semua permasalahan yang ada kemudian mengidentifikasi dan menganalisanya

\section{Hasil dan Pembahasan}

\section{A. Rencana Kebutuhan ((Requirement Planning)}

Pada tahap ini dilakukan analisa kebutuhan sistem informasi inventory barang pada PT. Cakra Medika Utama untuk merencanakan kebutuhan yang tepat, mengidentifikasi masalah dan memberikan solusi terhadap permasalahan yang dihadapi selama ini.

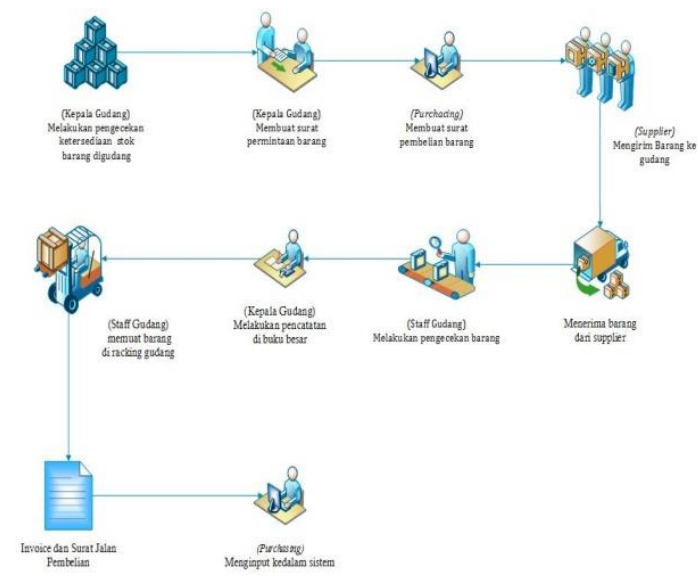

Gambar 2. Alur Proses Sistem Berjalan Barang Masuk masuk :

Bisnis proses sistem berjalan barang

- Kepala gudang melakukan pengecekan ketersediaan stok barang digudang.

- Setelah melakukan pengecekan stok barang yang sudah kosong atau sisa stok yang tinggal sedikit, kepala gudang membuatkan surat pemesanan barang kemudian surat pesanan tersebut diberikan kepada bagian purchasing.

- Dari surat pesanan tersebut bagian purchasing membuatkan surat pembelian barang yang akan dikirimkan kepada supplier.

- Sesuai surat pembelian barang yang telah dikirimkan, supplier mengirimkan barang ke gudang PT. Cakra Medika Utama bersama dengan invoice dan surat jalan.

- Staff gudang menerima barang sesuai surat jalan dari supplier dan melakukan 
pengecekan terhadap barang. Jika barang sudah sesuai maka staff memuat barang di racking gudang dan kepala gudang melakukan pencatatan barang masuk dibuku besar.

- Invoice dan surat jalan dari supplier diberikan kebagian purchasing kantor.

- Bagian purchasing menginput data pembelian barang kedalam sistem aplikasi Tabel Net, dan menyinpan atau mengarsip dokumen invoice dan juga surat jalan.

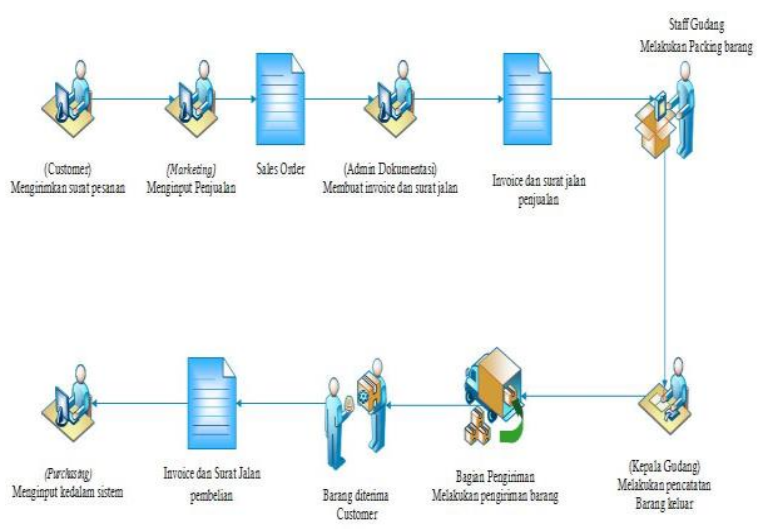

Gambar 3. Alur Proses Sistem Berjalan Barang Keluar keluar :

Bisnis proses sistem berjalan barang

- Customer mengirimkan surat pesanan barang ke bagian marketing

- Marketing menginput penjualan barang kedalam sistem Tabel Net dan membuat faktur Sales Order (SO)

- SO kemudian diberikan kebagian admin dokumentasi untuk diproses lebih lanjut.

- Admin dokumentasi membuat invoice penjualan dan surat jalan berdasarkan faktur SO yang diterima dari marketing.

- Dokumen invoice dan surat jalan dikirimkan kebagian gudang.

- Dari surat jalan yang diterima staff gudang menyiapkan dan melakukan pengecekan terhadap barang yang akan dikirim. Jika barang tidak mencukupi sesuai surat jalan dan invoice yang sudah diterbitkan dari kantor, maka invoice dan surat jalan dikembalikan ke bagian marketing untuk melakukan revisi, dan jika stok barang sudah sesuai surat jalan maka staff gudang melakukan packing barang dan memuat barang kedalam kedalam mobil box.

- Kepala gudang melakukan pencatatan barang keluar dibuku besar

- Kepala gudang melakukan pengawasan terhadap barang yang akan dikirimkan kepada customer.
- Bagian pengiriman melakukan pengiriman barang kepada customer bersama dengan invoice dan surat jalan yang akan diberikan kepada customer

- Barang diterima oleh customer

B. Metode Analisis Sistem

Tabel 1. Analisa PIECES

\begin{tabular}{|c|c|c|}
\hline $\begin{array}{c}\text { Jenis } \\
\text { Analisis }\end{array}$ & $\begin{array}{c}\text { Kendala Sistem } \\
\text { yang Sedang } \\
\text { Berjalan }\end{array}$ & $\begin{array}{c}\text { Solusi Sistem } \\
\text { yang Akan } \\
\text { Diusulkan }\end{array}$ \\
\hline $\begin{array}{l}\text { Performance } \\
\text { (kinerja) }\end{array}$ & $\begin{array}{l}\text { Menerima } \\
\text { Sales Order } \\
\text { tanpa } \\
\text { melakukan } \\
\text { pengecekan } \\
\text { stok barang } \\
\text { digudang } \\
\text { terlebih } \\
\text { dahulu. } \\
\text { Kepala } \\
\text { gudang } \\
\text { merangkap } \\
\text { pekerjaan }\end{array}$ & 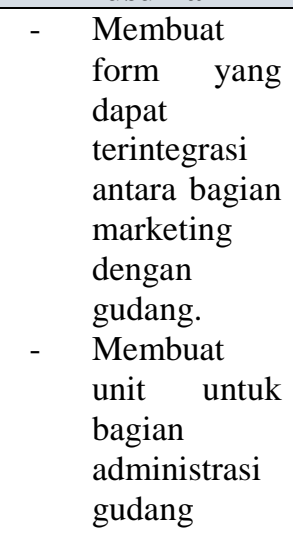 \\
\hline Information & 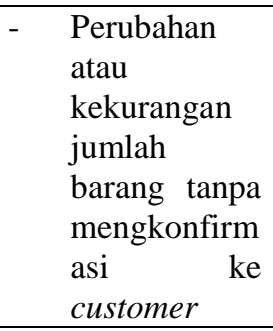 & $\begin{array}{ll} & \text { Membuat } \\
\text { notifikasi } \\
\text { terlebih } \\
\text { dahulu } \\
\text { sebelum } \\
\text { melakukan } \\
\text { revisi invoice }\end{array}$ \\
\hline Economic & $\begin{array}{l}\text { Biaya } \\
\text { operasional } \\
\text { tinggi } \\
\text { terutama } \\
\text { biaya } \\
\text { telekomunika } \\
\text { si dan alat } \\
\text { tulis kantor }\end{array}$ & $\begin{array}{ll}\text { - } & \text { Membuat } \\
\text { sistem yang } \\
\text { terintegrasi } \\
\text { antara gudang } \\
\text { dengan } \\
\text { marketing agar } \\
\text { dapat } \\
\text { meminimalisir } \\
\text { biaya } \\
\text { telekomunikasi }\end{array}$ \\
\hline Control & $\begin{array}{l}\text { - Form } \\
\text { approval } \\
\text { untuk kepala } \\
\text { gudang tidak } \\
\text { ada yang } \\
\text { sering } \\
\text { membuat } \\
\text { kesulitan } \\
\text { dalam } \\
\text { mengontrol } \\
\text { keluar masuk } \\
\text { barang dari } \\
\text { gudang } \\
\text { Sulitnya } \\
\text { mengontrol }\end{array}$ & $\begin{array}{ll}\text { - } & \text { Menyediakan } \\
\text { form approval } \\
\text { untuk } \\
\text { menyetujui } \\
\text { keluar masuk } \\
\text { barang dari } \\
\text { gudang } \\
\text { Menyediakan } \\
\text { form pemberitahuan } \\
\text { untuk barang } \\
\text { yang sudah } \\
\text { mau mendekati } \\
\text { tanggal } \\
\text { kadaluarsa }\end{array}$ \\
\hline
\end{tabular}




\begin{tabular}{|c|c|c|}
\hline & $\begin{array}{l}\text { barang yang } \\
\text { sudah mau } \\
\text { kadaluarsa }\end{array}$ & $\begin{array}{l}\text { yang sudah } \\
\text { ditentukan }\end{array}$ \\
\hline Efficiency & $\begin{array}{ll}\text { - } & \text { Adanya } \\
\text { revisi } \\
\text { invoice } \\
\text { setelah } \\
\text { penerbitan } \\
\text { invoice } \\
\text { tanpa } \\
\text { melakukan } \\
\text { pengecekan } \\
\text { stok barang } \\
\text { terlebih } \\
\text { dahulu } \\
\end{array}$ & 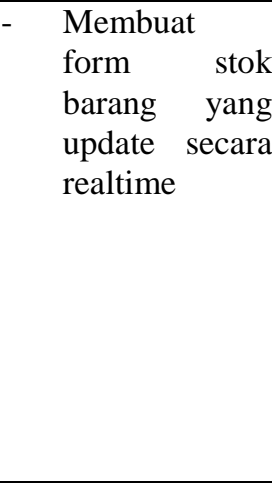 \\
\hline Service & $\begin{array}{l}\text { Tidak } \\
\text { memberika } \\
\mathrm{n} \text { hak akses } \\
\text { pada } \\
\text { bagian } \\
\text { gudang } \\
\text { untuk } \\
\text { menginput } \\
\text { data keluar } \\
\text { masuk } \\
\text { barang } \\
\text { kedalam } \\
\text { sistem }\end{array}$ & $\begin{array}{l}\text { - Membuat } \\
\text { sistem } \\
\text { persediaan } \\
\text { barang yang } \\
\text { dapat } \\
\text { memudahkan } \\
\text { bagian } \\
\text { gudang } \\
\text { dalam } \\
\text { menginput } \\
\text { keluar masuk } \\
\text { barang dan } \\
\text { juga dapat } \\
\text { meberikan } \\
\text { informasi } \\
\text { stok barang } \\
\text { yang lebih } \\
\text { cepat dan } \\
\text { akurat. }\end{array}$ \\
\hline
\end{tabular}

\section{Proses Desain Sistem (Design System)} 1). Workflow Diagram Sistem Usulan

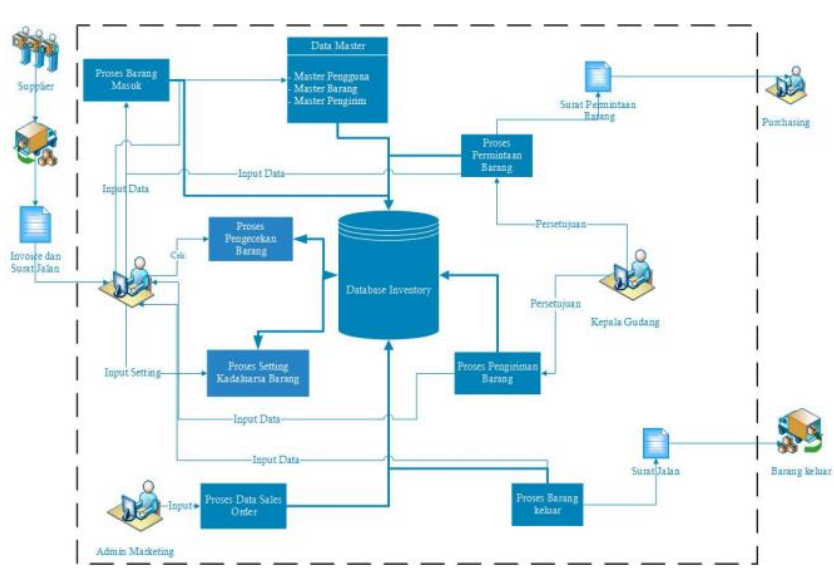

Gambar 4. Workflow Diagram Sistem Usulan

\section{2). Perancangan Antar Muka}

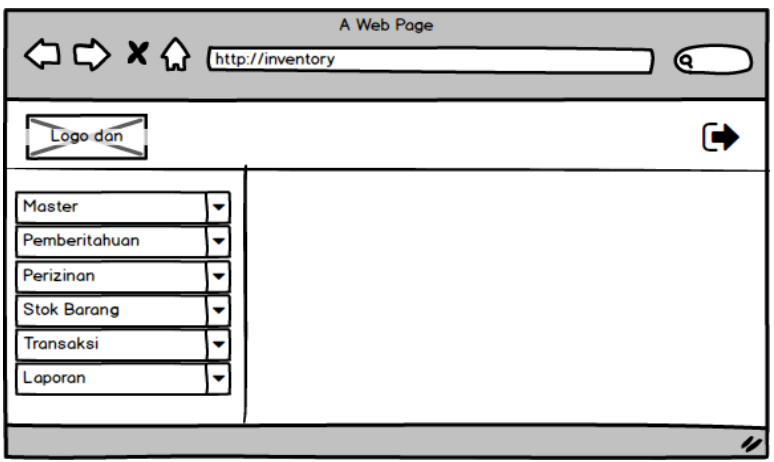

Gambar 5. Tampilan Halaman Utama

Gambar 5 di atas merupakan tampilan utama dari aplikasi setelah user berhasil memasukkan sandi dengan benar pada halaman login.

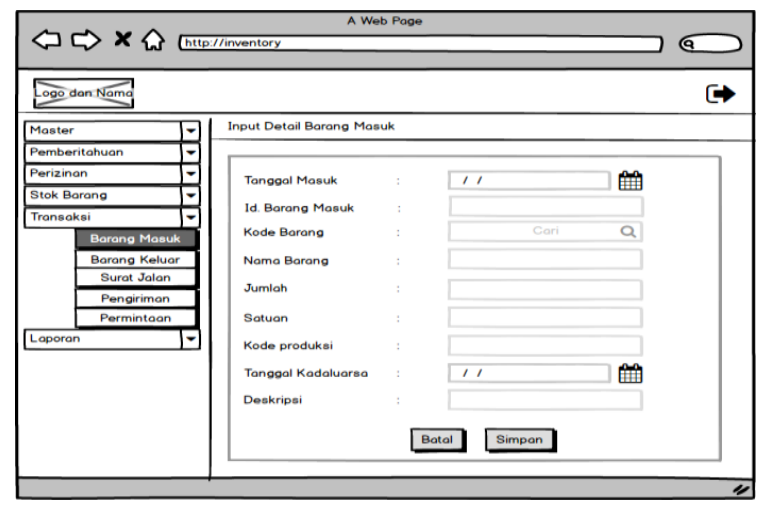

Gambar 6. Rancangan Tampilan Form Input Barang Masuk

Gambar 6 diatas merupakan form untuk menginput setiap item barang yang masuk terdiri dari ketegori tanggal masuk, id barang, kode barang, nama barang, jumlah, satuan, kode produksi dan tanggal kadaluarsa barang.

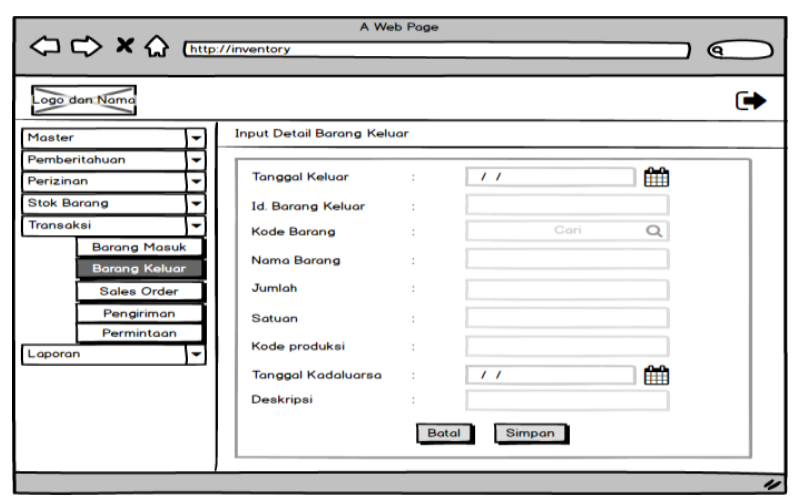

Gambar 7. Rancangan Tampilan Form Input Barang Keluar

Gambar 7 diatas merupakan form untuk menginput setiap barang yang keluar dari gudang terdiri dari ketegori tanggal keluar, id barang, kode 
barang, nama barang, jumlah, satuan, kode produksi dan tanggal kadaluarsa barang.

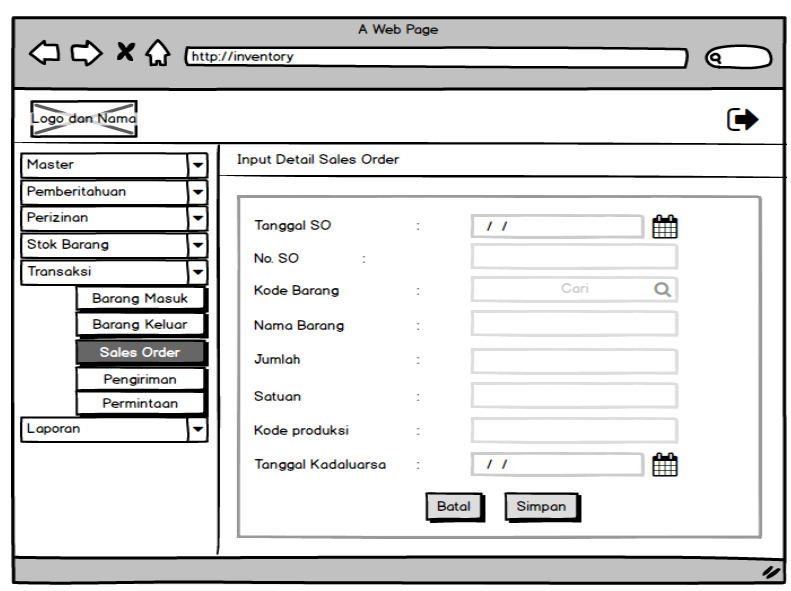

Gambar 8. Rancangan Tampilan Form Input Sales Order

Gambar 8 diatas merupakan form untuk menginput Sale Order yang digunakan untuk menjadi acuan pengecekan ketersediaan barang digudang sebelum penerbitan invoice penjualan.

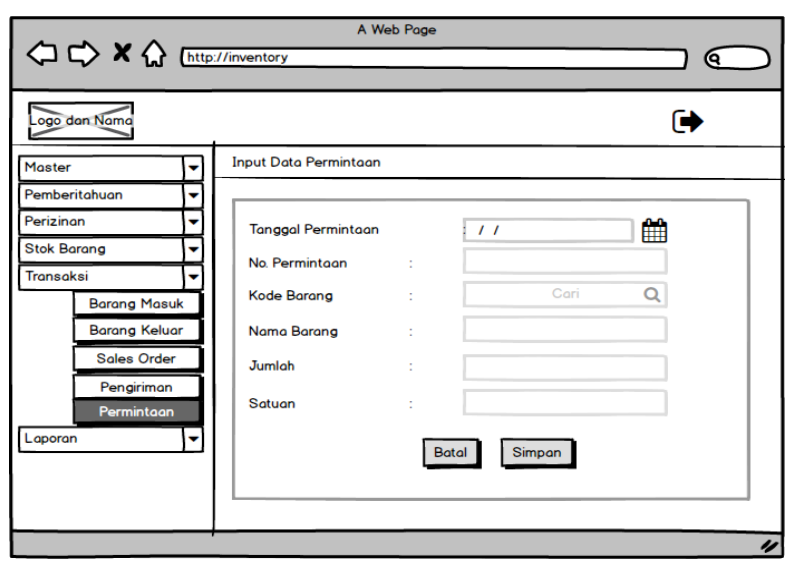

Gambar 9. Rancangan Tampilan Form Input Permintaan Barang

Gambar 9 diatas merupakan form untuk menginput permintaan barang yang nantinya akan menjadi acuan bagian purchasing untuk melakukan pembelian barang.

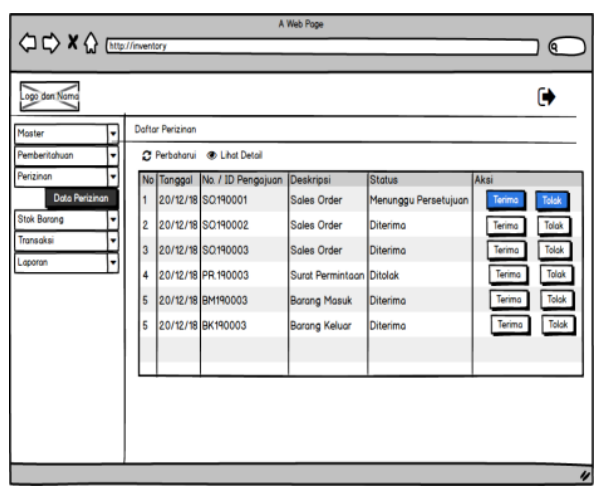

Gambar 10. Rancangan Tampilan Perizinan
Gambar 10 diatas merupakan tampilan data permintaan persetujuan kepala gudang, dimana setiap data permintaan persetujuan mempunyai antara 2 pilihan yaitu diterima atau ditolak.

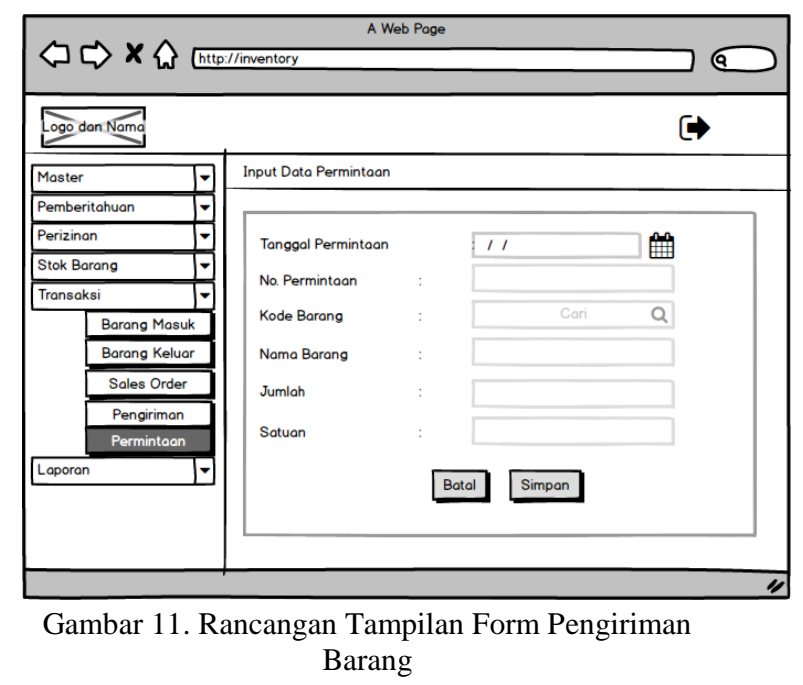

Gambar 11 diatas merupakan form untuk menginput data identitas pengirim barang yang terdiri dari kategori tanggal pengirim, id pengirim, nama pengirim, no. Handphone, jenis kendaraan dan plat kendaraan.

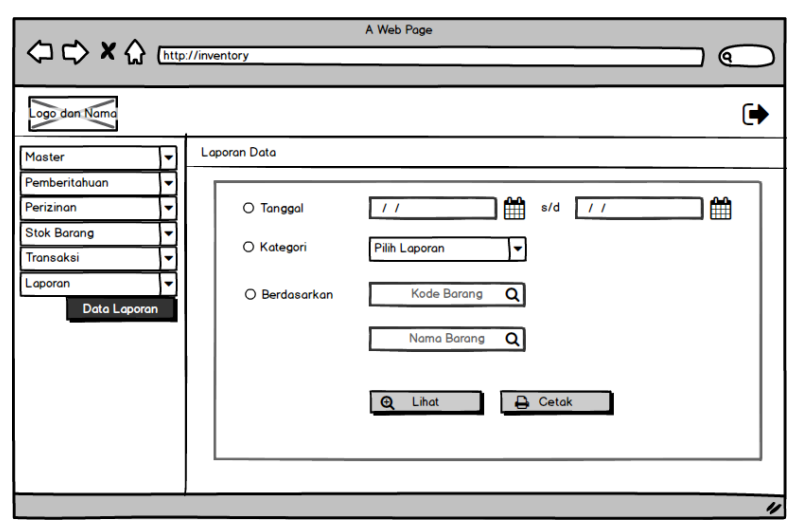

Gambar 11. Rancangan Tampilan Laporan Data

Gambar 11 diatas merupakan tampilan yang digunakan untuk membuat laporan data yang dibutuhkan.

\section{Penutup}

Berdasarkan penelitian yang telah dilakukan, maka dapat ditarik kesimpulan yaitu perancangan sistem ini dapat membantu meningkatkan efisiensi waktu dalam memberikan informasi ketersediaan stok barang yang ada digudang secara cepat dan akurat dan dapat meningkatkan efisiensi waktu dalam pencatatan persediaan barang masuk dan keluar secara update 
dan realtime dan membantu meminimalisir kerugian atas barang yang melewati batas tanggal kadaluarsa.

\section{Referensi}

[1] Priskila, ressa. 2018. "Perancangan Sistem Informasi Persedian Barang Pada Perusahaan Karya Cipta Sentosa Berbasis Web Dengan Metode Extreme Programing”. Journal Of Computer Engineering System And Science. pISSN:2502-7131, e-ISSN:2502714x.Vol.3, No.2:94-99. Juli 2018.

[2] Veza, Okta., And Ropianto, M. 2017. "Perancangan Sistem Invormmasi Invetory Data Barang Pada PT. Andalas Berlian Motor: Studi kasus PT Andalas Berlian Motors Bukit Tinggi”. Jurnal Teknik Ibnu Sina. ISSN:2541-2647,Vol.2, No.2:121134. Oktober 2017.

[3] Ramadhani, Annisa Ridha., Bunyamin and Fitriani, Leni. 2016. "Perancangan Aplikasi Persediaan Barang dan Transaksi Penjualan Barang di Alya Store”. Jurnal Algoritma Sekolah Tinggi Teknologi Garut. ISSN: 2302-7339 Vol. 13 No. 1 2016.

[4] Kurniawan, Helmi. 2016. "Perancangan Aplikasi Sistem Pengendalian Stock Barang Pada UD. Makmur Jaya Design Application Control System Stock goods in UD. Makmur Jaya”. Jurnal Ilmiah SISFOTENIKA. Vol. 6, No. 2, Juli 2016

[5] Syafarina, Gita Ayu. 2016. "Perancangan Aplikasi Inventory Barang Material Dan Product". Jurnal Ilimiah Fakultas Teknik "Technologia". Vol.7,No.1:25-33. JanuariMaret 2016

[6] Rahmad, Mhd Bustanur., and Setiady, Tedy. 2014. "Perancangan Sistem Informasi Invetory Spare Part Elektronik BerbasisWeb PHP: Studi CV. Human Global Service Yogyakarta”. Jurnal Sarjana Teknik Informatika. e-ISSN:23385197, Vol.2, No.2:1331-1340. Juni 2014.

[7] Rahadi, Adysta., Musadieq, Mochammad Al., And Susilo, Heru. 2014. "Analisis Dan Desain informasi Persedian Barang Berbasis Komputer: Studi Kasus Pada TokoArta Boga". Jurnal Administrasi Bisnis. Vol.8, No.2:1-8. Maret 2014.

[8] Rahman, Auliya. 2016. "Analisis Dan Implementasi Sistem Aplikasi Inventory
Items Berbasis Web Menggunakan Framework Codeigniter". Jurnal Al Ulum Sains dan Teknologi. Vol.2 No.1

Nopember 2016.

[9] Wahyuningrum, Tenia., And Januarita, Dwi. 2014. "Perancangan Web Ecommerce Dengan Metode Rapid Aplication Development". Seminar Nasional Teknologi \& Komunikasi Terapan 2014. ISBN: 979-26-0276-3. Semarang 15 November 2014.

[10] Susilowati, Seni. 2016. "Perancangan Model Sistem Informasi Dan Pengolahan Data Karyawan Berbasis Web Pada PT. Modelatama Banteng Sejati. 